\title{
(Nowe) trendy w muzealnictwie - spojrzenie subiektywne
}

\section{Wstęp}

W niniejszym artykule postaram się przedstawić subiektywne kierunki rozwoju nowoczesnego muzeum, przybliżając zagadnienia związane z zmianą podejścia do widowni muzealnej, zaprezentować argumenty przemawiające za przedsiębiorczym podejściem do funkcjonowania muzeum (co oczywiście nie oznacza transformacji muzeum w przedsiębiorstwo) oraz podać kilka przykładów popierających tezę, iż jednym z bardziej interesujących i efektywnych narzędzi w zarządzaniu współczesnym muzeum jest networking.

„Czy dobrze (...) rozumiemy, jak bardzo zachodzące zmiany wpływają na naszą muzealną pracę? Jak zmienia się funkcja muzealnej wystawy, książki czy zajęć edukacyjnych? Jakim zmianom podlega sposób katalogowania i inwentaryzacji zbiorów?” [Niezabitowski 2015: 123]. Mimo, że powyższe słowa autorstwa dr. Michała Niezabitowskiego pochodzą z 2015 roku nadal są aktualne, a ze względu na obecną, zupełnie bezprecedensową, sytuację w jakie znalazł się świat u progu 2020 roku, zmagając się z pandemią koronawirusa SARS-CoV-2, która zmieniła drastycznie życie nas wszystkich, nabierają dodatkowej wagi.

By spróbować odpowiedzieć na powyższe pytania w pierwszej kolejności chciałbym zwrócić uwagę na to jak szybko zmienia się rzeczywistość w jakim funkcjonujemy. By lepiej to zobrazować odwołam się do wystąpienia konferencyjnego prof. Krzysztofa Wisłockiego z Politechniki Poznańskiej, 
w którym zaprezentował zestawienie pokazujące szybkość przemian naukowych i technicznych. Jak wskazuje autor „(..) kolejne przełomy w rozwoju twórczej myśli technicznej były efektem upowszechnienia się epokowych wynalazków - określono je pojęciem rewolucji. Charakterystyczne okresy i związane z nimi osiągnięcia techniczne warto przypomnieć w kontekście coraz bardziej skracającego się czasu pomiędzy kolejnymi etapami rozwoju" ". Profesor, poczynając od pierwszej rewolucji przemysłowej związanej z wynalezieniem pary i rozpoczęciem produkcji przemysłowej (2 poł. XVIII w.); poprzez drugą rewolucję przemysłową — wynalezienie elektryczności, silnika spalinowego i telefonu (od 2 poł. XIX w.); trzecią — rozwój transportu, telekomunikacji, elektroniki i automatyzacji (poł. XX w. - lata 90. XX w.); czwartą - powszechność przesyłu informacji (lata 90. XX w. - pocz. XXI w.); piątą - wprowadzającą nanotechnologie i biotechnologie oraz kolejną związaną z erą sztucznej inteligencji (trwające obecnie), wskazał na zmniejszające się zakresy czasowe w jakich powyższe rewolucje były przeprowadzane poczynając od ponad 100 lat (przy pierwszej) do czasu poniżej lat 20 (przy piątej). Przedstawiony przez prof. Wisłockiego zarys rozwoju cywilizacyjnego w ostatnich stuleciach obrazuje, w jak szybko zmieniających się realiach przyszło nam żyć. To zaś uświadamia, jak niezwykle ważne w pracy muzealnika jest wyrobienie nawyku zadawania pytań o rolę muzeum, jego cele i sposoby działania. Nawyk rewidowania i aktualizacji naszych zamierzeń, innymi słowy „czytania gry” i szybkiego reagowania na zmiany doborem odpowiednich działań i narzędzi jest w moim przekonaniu niezbędny. Jeśli nie będziemy tego robić to bardzo szybko może się okazać, że stracimy kontakt z naszymi odbiorcami, że nie jesteśmy dla nich atrakcyjni, co skutkować zapewne będzie zmniejszeniem zainteresowania muzeami.

\section{Społeczna rola muzeów}

Od lat spieramy się w naszym środowisku o istotę muzeum i pracy muzealników, o to, jaki winien być status muzeum i muzealników, o to, jaka jest rola i pozycja zwiedzającego, odbiorcy czy też widza.

Przytaczając raz jeszcze słowa dr. Niezabitowskiego: „,w minionych latach dominował paradygmat funkcji ochronnych i konserwatorskich, a samo

\footnotetext{
${ }^{1}$ Prof. Krzysztof Wisłocki, prelekcja pt. Wybrane aspekty współdziałania uczelni technicznych i muzeów w ochronie zabytków sztuki inżynieryjnej podczas konferencji naukowej Technika i nauka w muzeum, Bydgoszcz, 25.09.2019.
} 
muzeum definiowano jako instytucja gromadzenia i ochrony zbiorów. Obecnie tradycyjny paradygmat mocno ściera się z perspektywą, która akcentuje funkcje edukacyjne i społeczne” - możemy zauważyć istotną zmianę w podejściu do roli muzeum, a tym samym do publiczności [Niezabitowski 2015: 122].

Bliskie jest mi podejście do widza jako do współ-uczestnika, który jest dla muzealnika partnerem w procesie poznania i rozwoju.

Czy w dzisiejszych muzeach mamy nadal do czynienia ze zwiedzającym? W języku polskim słowo „zwiedzać” ma ścisły związek znaczeniowy z terminami „widzieć” i „wiedzieć”. Obecnie muzealny gość nie chce tylko widzieć i wiedzieć, ale pragnie przeżywać i brać aktywny udział w narracji o sztuce i dziedzictwie. Bardziej adekwatne byłoby zatem określenie „uczestnik” lub — jeszcze precyzyjniej — „partycypant” [Niezabitowski 2015: 122].

Coraz mocniej w środowisku muzealnym przebija się głos o zaniechaniu komunikacji jednostronnej, z pozycji eksperta, zmierzając raczej do wykreowania sytuacji, w której uczestnik sam dochodzi do własnych wniosków/interpretacji, gdzie wspólnie dzielimy się wiedzą i doświadczeniem. Zgodnie z postulatami prezentowanymi w publikacji Lokalne muzeum w globalnym świecie: „muzeum udziela głosu użytkownikowi, a nie tylko formuje własny przekaz” i „muzeum stawia pytanie, a nie tylko udziela odpowiedzi” - ma być inspiracją i miejscem rozwoju osobistego, a nie jedynie platformą przekazu danych [Hajduk, Piekarska-Duraj, Idziak 2013: 10].

Jak czytamy w Strategii Rozwoju Muzealnictwa: „muzeum kształtuje i współtworzy przestrzeń komunikacji i socjalizacji społecznej, rozwijania „miękkich” kompetencji, które stanowią między innymi o umiejętności nawiązywania dialogu, krytycznego oglądu, samokontroli i samodoskonalenia, wzrostu świadomości i pewności siebie, umiejętności samostanowienia, asertywności, empatii” [Hibner, Łysik, Pater, Skotnicka-Illasiewicz, Stępień, Surdej, Wrede, Rataj 2012: 119].

Czy jesteśmy gotowi na takie podejście do widza/odbiorcy/uczestnika, czy wizja mocnego akcentu postawionego na pracę i partnerski dialog z osobami odwiedzającymi muzea jest dla nas atrakcyjna i chcemy ją realizować? Czy wreszcie - nie takie właśnie są oczekiwania i potrzeby społeczne?

Doświadczenia bydgoskiego Muzeum Okręgowego (MOB) i statystyki frekwencyjne pokazują dość wyraźnie, że znacząca większość osób korzystających z oferty muzealnej — wystaw, działań edukacyjnych i wszelkiej 
maści wydarzeń - wybiera uczestnictwo w działaniach, w których są partnerami, współuczestnikami i mogą być aktywni. Niemal 70\% wejść do MOB (z całościowej frekwencji rocznej) w roku 2018 dotyczyła osób, które skorzystały z oferty edukacyjnej i eventowej muzeum (przy czym 45\% to uczestnicy działań edukacyjnych). Dlatego też obserwując zainteresowanie i zapotrzebowanie na działania edukacyjne i eventowe, których szeroko rozumianym celem jest rozwoju społeczeństwa oraz chcąc przyciągnąć do muzeum nową widownię, winniśmy otworzyć się na ww. potrzeby uczestnika, co zapewne skutkować będzie tym, że muzeum wzmocni i rozwinie pozycję ważnego gracza na rynku rozwoju społecznego.

Nowy człowiek to również nowy widz w muzeach. Coraz częściej zamiast poznania intelektualnego wybiera on poznanie sensualne-zmysłowe. Oczekuje też szybkiego dostępu do informacji, postrzegając zdobywanie wiedzy jako swoje prawo naturalne. Nie ulega wątpliwości, że środowisko muzealne, aby nie stracić kontaktu ze społeczeństwem, musi szybko dostosować swoją ofertę do potrzeb zmieniającej się publiczności. [...] Warto zauważyć, że wystawa jest obecnie platforma dialogu ze zwiedzającym, który powoli przestaje być wiernym widzem, a staje się uczestnikiem interaktywnej przygody — nie jest już jedynie pasywnym odbiorcą, uczestniczy w kreacji, wchodząc w rolę „aktora” i współtworząc doświadczenie muzealne [Niezabitowski 2015: 122].

Waszak „słowo uczestniczyć oznacza bowiem nie tylko tworzyć, percypować i interpretować, ale przede wszystkim współtworzyć pewną sytuację lub zbiorowość, w której bierzemy udział, wpływać na nią przez swoje działania lub samą w niej obecność” [Krajewski 2013: 48].

Pomimo otwierania się muzeów na odbiorcę, a nawet stawiania widza w centrum zainteresowania, widoczny jest mocno zarysowany podział na dwa stronnictwa. Jedno - stawiające prymat muzealiów ponad inne wartości, które stanowią element dodany do muzealnego artefaktu; drugie - stawiające obok znajdującego się w centrum muzealium — odbiorcę/ uczestnika. Tak jak bez muzealników nie ma zbiorów, a bez zbiorów nie ma muzeum, tak bez odbiorców funkcjonowanie muzeów jest porostu mało zasadne. Warto zadać sobie pytanie - po co gromadzimy kolekcje muzealne? Dla stronnictwa, dla którego odbiorca jest sercem współczesnego muzeum, to rozwój owego odbiorcy/uczestnika będzie prymarny. Jeśli więc obok muzealium postawimy naszego odbiorcę, jako partnera i wejdziemy z nim relację, nie uciekając od podejmowania aktualnie ważkich tematów, 
to mamy szansę stać się istotnym miejscem rozwoju osobistego członków różnych społeczności — zwłaszcza społeczności lokalnej. Wszak „muzeum tworzy przestrzeń do dyskusji i bierze udział w tej dyskusji”, „muzeum służy społeczeństwu a nie samemu sobie" — to kolejne cytaty z Lokalnego muzeum [Hajduk, Piekarska-Duraj, Idziak 2013: 10].

Warto w tym miejscu zwrócić uwagę na dość powszechną chorobę zawodową muzealników, jaką jest tzw. „klątwa wiedz”, która objawia się w przekonaniu, że taką samą, bądź odbiegającą nieco od naszej, wiedzę posiadają osoby korzystające z oferty muzeów. Efektem tej jednostki chorobowej jest zbyt mała dbałość o wyjaśnianie kontekstów, terminów, założeń kuratorskich i zadań przypisanych eksponatom czy wręcz próba oddawania „głosu artefaktom”. Taki stan rzeczy powoduje, iż znacząca część odbiorców nie jest w stanie odczytać zakodowanych treści, bądź przebrnąć przez teksty przeładowane metajęzykiem i wymyślnymi terminami. Skoro więc przeciętny odbiorca zwiedzając wystawę, która przygotowana jest do odbioru przez specjalistów w danym zakresie albo stawia wymaganie wcześniejszego przygotowania, niewiele wyniesie z tego doświadczenia, to następnym razem dwa razy zastanowi się nad tym czy przyjść ponownie do muzeum. Mając poczucie braku wystarczającej wiedzy będzie czuł się niekomfortowo, a nikt z własnej woli do takiej sytuacji nie dąży. Wyleczenie się z choroby „klątwy wiedzy” i próba budowania ekspozycji w ten sposób, by była dostosowana do konkretnych grup odbiorców, czy to poprzez proces partycypacji, realizację badań czy też włączania do zespołu realizacji wystaw pracowników muzeum, którzy najlepiej znają naszego odbiorcęczyli edukatorów muzealnych, na co dzień pracujących z widzami — jest szansą na stworzenia ekspozycji, która zadowoli zarówno twórców, jak i odbiorców. Warto przyjąć założenie, by tak zaprojektować wystawę, by można ją zwiedzać indywidualnie, odczytując zawarte w niej treści i móc przeżyć osobiste doświadczenie, bez konieczności wynajmowania przewodnika, czy „googlowywania” w internecie.

Obecnie zdecydowanie mniejsze znaczenia mają działania polegające na przekazywaniu faktów, które dość szybko i łatwo można uzyskać z różnych źródeł (w szczególności informatycznych), dlatego zdecydowanie ważniejsze jest tworzenie opowieści, czy też interpretacji, która jest skuteczniejsza, a której istotę niezwykle celnie określił w 1957 r. Freeman Tilden w swojej pracy Interpretacja dziedzictwa, pisząc „interpretacją nazywamy działania edukacyjne mające na celu odkrycie znaczeń i powiązań między 
poszczególnymi treściami dzięki wykorzystaniu zachowanych obiektów, bezpośredniego doświadczenia oraz środków ilustrujących, a nie poprzez samo przekazywanie faktów słowami” [Tilden 2019: 42].

Tilden, ojciec interpretacji dziedzictwa, stworzył sześć zasad sztuki interpretacji, z których najistotniejsze to:

- Interpretacja będzie jałowa, jeśli nie połączy tego, co prezentuje lub opisuje, z osobowością i doświadczeniem odbiorcy.

- Samo podanie informacji nie jest interpretacją. Interpretacja to ujawnienie znaczeń ukrytych pod informacją. Choć interpretacja zawsze zawiera element informacji, są to dwie całkiem odrębne kategorie. [...]

- Głównym celem interpretacji nie jest nauczanie, lecz pobudzanie do myślenia.

- Interpretacja powinna mieć na celu przekazanie wizji całości, a nie tylko części. Jej adresatem powinien być człowiek w całej swojej złożoności [Tilden 2019: 44].

Słowa Freemana Tildena, które mają już ponad 60 lat, są nie tylko cały czas aktualne, ale mam wrażenie, że nadal są pewną awangardą, do której w moim przekonaniu zbyt rzadko sięgamy w procesie budowania przekazu, nie zawracając odpowiedniej uwagi na uczestnika, a przecież jak pisał Tilden „[...] odwiedzających najbardziej interesuje to, co bezpośrednio dotyka ich samych — ich osobowości, doświadczeń i przekonań” [Tilden 2019: 47].

Tworząc zatem wystawę, oprowadzając po niej, przygotowując działania eventowe czy zajęcia edukacyjne, warto skupić się na zbudowaniem całościowej opowieści, skierowanej do konkretnego odbiorcy, odnoszącej się do jego wiedzy czy doświadczeń, które zainspirują do dalszej aktywności. Tildenowski przepis na interpretację dziedzictwa, „skrojony” dla muzeów, stanowi gotową receptę na pracę w widzem.

Mocne otwarcie się części środowiska muzealnego na odbiorców spowodowało zainteresowanie koncepcją Trzeciego miejsca Ray’a Oldenburga i Dennisa Brissetta. Jak pisze Katarzyna Jagodzińska:

[...] w trzecich miejscach ludzie gromadzą się głównie po to, aby cieszyć się wzajemnie swoim towarzystwem. [...] Trzecie miejsca stanowią dla ich użytkowników lekarstwo na stres, samotność i wyobcowanie. Tutaj społeczność jest najbardziej żywa, a ludzie są najbardziej sobą. Są to nie-formalne publiczne miejsca spotkań. Co istotne jednak, nie każde miejsce spotkań pomiędzy domem i pracą (lub nauką) jest trzecim miejscem. Trzecie miejsce stało się popularnym słowem-kluczem 
dla miejsc, w których odbywają się procesy socjalizacji — nie tylko takich, tradycyjnie łączonych z rozrywką, ale także wiedzą (biblioteki, muzea). Koncepcja ta omawiana jest z perspektywy różnych dyscyplin, w tym studiów muzealnych, chociaż do muzeów Oldenburg się nie odnosi. Spojrzenie na muzea właśnie jako na miejsca, gdzie w sposób niezobowiązujący spędza się czas wolny oddając towarzyskiej rozmowie, okazało się dla muzealników i muzeologów bardzo kuszące. Wielu autorów wskazuje jednak, że teoria trzeciego miejsca nie przystaje do muzeów [Jagodzińska 2018: 125].

Czy muzeum może wypełnić założenia teorii trzeciego miejsca? Dyskusja na ten temat jest nadal aktualna. Nie zmienia jednak to faktu, że niezwykle atrakcyjną wydaje się być wizja wpisania instytucji muzealnych w format miejsca przyjemnie się kojarzącego, gdzie rozwija się kontakty i buduje relacje, które służy społecznościom i jest ważne dla wielu jej członków.

Postawienie silnego akcentu społecznego widoczne jest w nowej propozycji definicji muzeum przedłożonej, dyskutowanej i ... nieprzyjętej (odesłanej do dalszych prac) podczas XXV Konferencji Generalnej Międzynarodowej Rady Muzeów ICOM w Kyoto, odbywającej się we wrześniu 2019 r. Dyskutując w licznym gronie muzealników z całego świata, zastanawiano się m.in. nad otwarciem instytucji muzealnych na nowe zadania, by muzea poza byciem powiernikami dziedzictwa materialnego i niematerialnego oraz strażnikami pamięci dla przyszłych pokoleń, stały się przestrzeniami krytycznego dialogu przeszłości z przyszłością. By mogły być takimi podmiotami, które „opierają się na współuczestnictwie i jawności, współpracują aktywnie i na partnerskich zasadach z różnymi społecznościami, aby zbierać, przechowywać, badać, interpretować, wystawiać oraz pogłębiać rozumienia świata, a przez to przyczyniać się do wzmacniania godności ludzkiej i sprawiedliwości społecznej, globalnej równości i dobrostanu naszej planety” [Wasilewska 2019: 176].

W powyższej propozycji definicji muzeum widoczna jest próba nadążania za dynamicznie zmieniająca się rzeczywistością, w której to muzea stają się aktywnymi partnerami dla (różnych) społeczności w podejmowaniu dyskursu o rzeczach aktualnie ważnych.

Kolejnym ważnym zadaniem jakie stoi przed muzeami - nawiązującym do omawianego uspołecznienia muzeów — jest zobowiązanie i trud dbania o lokalną przestrzeń, zgodnie z założeniami przyjętymi w roku 2016 w Mediolanie na konferencji ICOM-u w rezolucji The Responsibility of Museums Towards Landscape. Znane są przypadki, gdy muzea stają się stronami 
w dyskursie, a czasem nawet sporze o przestrzeń miejską (okołomuzelaną), której grozi degradacja. Niech za przykład posłużą dwa przypadki: Muzeum Pałacu Króla Jana III w Wilanowie i Muzeum Śląskiego w Katowicach, które to podjęły aktywne działania na rzecz zachowania przestrzeni o znaczących walorach historycznych, znajdujących się w bezpośrednim sąsiedztwie muzeów, które to miały zostać przekształcone na osiedla mieszkaniowe. Taka aktywność, pozornie stojąco obok głównych celów muzeów, pokazuje, że instytucje muzealne stają się partnerami w dyskursie społecznym nie tylko w zakresie gromadzonego dziedzictwa, ale również kształtowania przestrzeni miejskich, budując (niejako przy okazji) markę muzeum jak instytucji odpowiedzialności i zaufania społecznego.

\section{Przedsiębiorcze muzeum}

Muzea funkcjonują pomiędzy misją a wolnym rynkiem, pomiędzy lokalnością a globalizacją, pomiędzy potrzebami indywidualnych osób a szerokiego ruchu turystycznego i w takich realiach muszą znaleźć swoją drogę do bycia aktywnym, a nawet przedsiębiorczym.

Wspierając aktywność poznawczą zwiedzających, muzea w znacznej mierze mogą pomóc we wspieraniu i rozwoju tzw. „kapitału ludzkiego” będąc inspiracją dla nowych zainteresowań, słuząc pomocą w przekwalifikowaniu się kadr, tworzenia nowych zawodów w różnych dziedzinach wiedzy, tym samym wspierając rozwój gospodarczy poprzez rozwój przemysłu kulturowego tworząc tzw. „klastry kultury” [...] [Hibner, Łysik, Pater, Skotnicka-Illasiewicz, Stępień, Surdej, Wrede, Rataj 2012:].

Jak jednak stać się przedsiębiorczym muzeum? Jak funkcjonować na wolnym rynku, nie rezygnując jednocześnie działań misyjnych?

Prof. Aleksander Surdej w następujący sposób widzi szansę dla rozwoju muzeów:

[...] wzrost zamożności ludności wielu państw wyrażający się wzrostem jej siły nabywczej oraz wzrost ilości czasu wolnego sprawiają, że rośnie zainteresowanie ofertą kulturalną: od muzycznej do muzealnej. W takich warunkach instytucje kultury zyskują szansę stania się protagonistami rozwoju gospodarczego i ważnym czynnikiem podnoszenia jakości życia i dobrostanu ludności. Wykorzystanie tej szansy zależy w znacznym stopniu od sposobu zarządzania instytucjami kultury [Surdej 2019: 59]. 


\section{I dalej:}

[...] instytucje kultury, chcąc wykorzystać pojawiające się możliwości, powinny interpretować swoją misję w sposób innowacyjny, traktując przedsiębiorcze nastawienie jako narzędzie działania. Współczesne muzea powinny podejmować innowacyjne przedsięwzięcia muzealne i edukacyjne, powinny być platformami innowacji rozwijając i wdrażając twórcze pomysły i wspierając twórców kultury [Surdej 2019: 59].

Nie ulega wątpliwości, że muzea są graczami rynku czasu wolnego, konkurując, czasem współpracując z innymi, nierzadko komercyjnymi podmiotami, jeśli nie podejmą gry to zostaną zepchnięte na margines, a muzealnicy za swoją pracę, która często nie odbiega jakościowo lub jest na wyższym poziomie niż u komercyjnych podmiotów, będą wynagradzani znacznie gorzej.

Podobnie do prof. Surdeja widzi przyszłość muzeów Geralt Matt, stierdzając: „w rozwiniętym społeczeństwie wolnego czasu i technologicznie zaawansowanych mediów również muzea zmuszone są przyjąć warunki konkurencji i coraz bardziej kurczącego się, możliwego do zagospodarowania kapitału uwagi publiczności” [Matt 2006: 158].

W jaki sposób jednak doprowadzić do tego, by muzeum stało się przedsiębiorcze? To pytanie, na które w moim przekonaniu nie ma jednej i łatwej odpowiedzi m.in. dlatego, że świat muzealny jest niezwykle różnorodny, zarówno pod względem charakterystyki zbiorów, wielkości instytucji, struktury zatrudnienia, uwarunkowań topograficznych czy też organizacyjnych, niemniej chciałbym wskazać na kilka elementów, które wydają się mieć niebagatelne znaczenie.

Kluczową rolę w tym procesie odgrywa lider instytucji, czyli dyrektor. Osoba, często osobowość, która winna nadawać kierunek zmian, wyznaczać kurs muzealnej załodze, motywować i zaraża wizją swoich współpracowników. To osoba, której zadaniem jest tworzenie głównej sieci relacji łączącej muzeum z partnerami (o organizatorze nie zapominając).

Nie mniej ważny w procesie rozwoju muzeum jest zespół pracowników. Bo to zespół, ludzie tworzą muzeum, bez zespołu nie będzie istniało muzeum. Jak wskazuje Gerald Matt:

[...] w muzeum pojmowanym jako przedsiębiorstwo usługowe personel stanowi jeden z najistotniejszych elementów kształtujących potencjał skuteczności. Zdolni do osiągania sukcesu i nastawieni na 
sukces pracownicy nie są wprawdzie gwarancją sukcesu przedsiębiorstwa - brak potencjału osobowego lub niezdolność wykorzystania tego potencjału mają jednak ogromne następstwa dla pozycji przedsiębiorstwa we współzawodnictwie w pozyskiwaniu dzieł, artystów i odwiedzających. Management personalny [...] należy więc do pierwszorzędnych i najważniejszych zadań, przed jakimi staje kierownictwo muzeum [Matt 2006: 103].

O tym, jak istotny dla funkcjonowania muzeów jest zespół profesjonalnych i zaangażowanych pracowników, przekonujemy się niemal każdego dnia, a ekstraordynaryjna sytuacja muzeów w czasie pandemii SARS-CoV-2 dobitnie to potwierdziła, pokazując niejednokrotnie, jak duży potencjał (często do tej pory ukryty) tkwił na zespołach muzealnych. Kluczowe jest jednak to, by ten potencjał potrafić wykorzystać.

Odpowiednie budowanie zespołu pracowników o różnorodnych kompetencjach, kreatywnego i umiejącego współpracować jest procesem ciągłym i trudnym do przecenienia. Jednym z często obserwowanych problemów jest atomizacja pracowników (głównie na poziomie działów), która nie sprzyja współpracy, a czasem wręcz ją uniemożliwia, dlatego też praca na rzecz otwartości międzystrukturalnej, chęci i umiejętności współpracy międzydziałowej, połączona z identyfikacją z muzeum i pozostałymi członkami zespołu (dobrym komunikowaniem) jest wyzwaniem dla wielu instytucji.

Niektóre muzea zmieniając swoje myślenie o roli, jaką mają pełnić, idą zdecydowanie w kierunku aktywizacji, przedsiębiorczości i permanentnej zmiany, powołując w swoich strukturach komórki odpowiedzialne za przeprowadzanie owych zmian, zwane często działami rozwoju. To interesujące podejście zarządcze, warte bliższemu przyjrzeniu.

Zwiększa się również liczba muzeów podchodzących do zarządzania w sposób strategiczny.

Zgodnie z definicją Moltkego „strategia to trzymanie się w postępującym naprzód działaniu pierwotnie obranej idei przewodniej, stosownie do stale zmieniających się okoliczności”. W przypadku muzeum oznacza to, że wyznaczone na podstawie Mission Statement i obrazu przewodniego cele strategiczne i środki operacyjne przechodzą w fazę realizacji. Cele strategiczne cechuje długofalowość, wpisane jest w nie na stałe pytanie czym muzeum chce być na przyszłość. Cele operacyjne są średnio- i krótkookresowe i są etapami do osiągnięcia celów strategicznych. [...] Strategia [...] określa, w jakich obszarach, z jakich powodów i za pomocą jakich środków przedsiębiorstwo chce 
w przyszłości działać. Strategię charakteryzują podstawowe kierunki działania, dające się określić cele i czasowe następstwa podejmowanych zasadniczych kroków [Matt 2006: 55].

Znane są przykłady konsekwentnego zarządzania muzeum w oparciu o strategię. Jednym z nich jest Muzeum Krakowa, które w latach 2005-2006 wypracowało pierwszą strategię i od tego czasu opiera swoją działalność o dokumenty strategiczne (obecnie realizowana jest druga jej odsłona). Aby zarządzanie strategiczne było łatwiejsze do realizacji, wyodrębniono w strukturze instytucji komórkę, której zadaniem jest wdrażanie jej założeń, organizowane są również dorocznie konwenty strategiczne, podczas których pracownicy muzeum analizują coroczne osiągnięcia i dyskutują nad dalszymi posunięciami.

Istotnym i pożytecznym narzędziem, choć jeszcze rzadko wykorzystywanym w zarządzaniu, zarówno całą instytucją, jak i poszczególnymi projektami, jest controlling będący „swoistym instrumentem [...] zapewniającym instytucji dostęp do informacji wpływającej na wybór celów i określającej kierunek jej przyszłego rozwoju” i dalej „to instrument, który pozwala informację tę właściwie przygotować i w należyty sposób dla dobra instytucji wykorzystać. Chodzi tu w ostatecznym rozrachunku o analizę porównawczą stanu faktycznego ze stanem docelowym, a więc śledzenie odchyleń pojawiających się pomiędzy rezultatami działalności przedsiębiorstwa tu i teraz a wynikami, których osiągnięcie przedsiębiorstwo postulowało - chodzi tu również o ustalenie przyczyn tych odchyleń i w konsekwencji opracowanie ulepszonych, alternatywnych form działania" [Matt 2006: 194].

By móc realizować postulat muzeum przedsiębiorczego niezbędna jest także wiedza o rynku usług kulturalnych oraz preferencjach publiczności (jak również „niepubliczności”). Aby taką wiedzę posiadać, konieczne są cykliczne (wszak rzeczywistość szybko się zmienia) badania preferencji odbiorców kultury, gdyż „przedsiębiorstwo, które pragnie odnieść sukces, musi znać rynek i potrzeby swoich klientów” [Matt 2006: 157].

Tematem przedsiębiorczego muzeum zajęła się od 2019 roku Akademia Muzeum - projekt wymiany doświadczeń (sieciowania na poziomie krajowym) realizowany do 2018 r. pomiędzy czterema parterami: Muzeum Pałacu Króla Jana III w Wilanowie, Muzeum Narodowym Rolnictwa i Przemysłu Rolno-Spożywczego w Szreniawie, Muzeum Etnograficznym im. Seweryna Udzieli w Krakowie i Muzeum Okręgowym im. Leona Wyczółkowskiego 
w Bydgoszczy, którego prace koordynuje Kolegium Wigierskie. Członkowie Akademii (głównie dyrektorzy i osoby średniego szczebla zarządzania) do niedawna spotykali się 3-4 razy do roku, podejmując różne tematy i wymieniając się doświadczeniami. Problematyka przedsiębiorczego muzeum, obok edukacji i modeli zarządzania była jedną z najczęściej podejmowanych. Sytuacja znacząco zmieniła się w okresie pandemii, gdy prace Akademii przeniesiono do środowiska online, na realizowane w cyklu dwutygodniowym spotkania w trybie wideokonferencji. Tematem przewodnim, nadrzędnym obecnie prowadzonych prac stało się właśnie przedsiębiorcze muzeum - problematyka uznana przez osoby uczestniczący w projekcie za najistotniejszą i najszerzej oddziałującą na prace w muzeach. Przy czym termin „przedsiębiorcze” rozumiany jest zarówno pod kontem ekonomicznym, jak i rozwojowym.

Mocno niedoceniana, a niezwykle istotna dla (stałego) rozwoju muzeum jest tzw. „pamięć instytucji”. Silny lider z wizją i wypracowaną siecią partnerstw, który potrafi zmotywować i prowadzić zespół muzealny w założonym (wspólnie wypracowanym) kierunku jest dla instytucji nie do przecenienia. Jeśli jednak ów lider nie zadba o to, by sieć współpracy pomiędzy muzeum i podmiotami zewnętrznymi budowali również inni członkowie zespołu, to w sytuacji zakończenia pracy w danym muzeum przez dyrektora, instytucja zostaje pozbawiona wypracowanej sieci partnerstw. Pozostający w muzeum zespół, który nie zbudował sieci kontaktów i/lub nie przejął jej od dotychczasowego lidera, w konsekwencji musi tę pracę wykonać od początku. Stąd tak ważne jest to, by dzielić odpowiedzialność za budowanie relacji muzeum z partnerami pomiędzy dyrektora i zespół. Wypracowane kontakty winny być tak zapisywane w „pamięci instytucji” - czyli członków zespołu (wpisywane w rdzeń muzeum), by przetrwały zmiany dyrekcji i poszczególnych pracowników. Muzeów nie stać na to, by wykonywać tę samą pracę kilkukrotnie.

\section{Sieciowanie jako narządzie pracy muzealnej}

Czym zatem jest sieciowanie, zwane również networkingiem? Jak głosi jedna z definicji:

Networking to nawiązywanie kontaktów i utrzymanie pozytywnych relacji w celu wymiany informacji oraz wzajemnego wsparcia w sferze zawodowej. [...] To pielęgnacja znajomości, aby móc w razie potrzeby zwrócić się z pomocą do konkretnej osoby, która może i chce 
pomóc. [...] Sieć składa się z podmiotów o różnych kompetencjach i doświadczeniach co może ułatwiać realizację celów i jest szansą na wykreowanie działania o nowej jakości [www.mfiles.pl/pl/index.php/ Networking; data odczytu: 15.06.2020].

Sieciowanie to narzędzie, które dość nieoczekiwanie stało się jednym z elementów zarządzania wiedzą w Muzeum Okręgowym w Bydgoszczy. Obecnie MOB realizuje działania sieciujące na 4 poziomach: lokalnym, regionalnym, krajowym i międzynarodowym.

\section{POZIOM LOKALNY}

W 2013 r. powołane zostało Forum Muzeów Bydgoskich — nieformalne ciało współpracy międzymuzealnej w Bydgoszczy, które tworzyły i tworzą nadal (z pewnymi zmianami) bydgoskie muzea. Podstawowym przyczynkiem do powstania Forum było przygotowanie raportu prezentującego Stan i perspektywy rozwoju muzealnictwa w Bydgoszczy w latach 2013-2015. Taki raport powstał, a nawet dwie jego wersje (druga obejmowała okres do roku 2030), a dziewięć muzeów go tworzących doszło do wniosku, że chce współpracować dalej i czyni to do dnia dzisiejszego, choć w ostatnich latach jedynym elementem wspólnej pracy jest przygotowanie i przeprowadzenie bydgoskiej edycji Europejskiej Nocy Muzeów.

\section{Szlak Wody, Przemystu i Rzemiosła TeH2O w Bydgoszczy}

W roku 2012 narodził się w Bydgoszczy pomysł stworzenia miejskiego szlaku kulturowego poświęconego dziedzictwu przemysłowemu. Udało się go zrealizować w ramach międzynarodowego projektu SHIFT-X, prowadzonego przez Urząd Miasta Bydgoszczy. Celem projektu było usprawnienie struktur zarządzania dziedzictwem poprzemysłowym, a także stworzenie zupełnie nowych produktów tegoż dziedzictwa. W ten sposób powstał Szlak Przemysłu, Wody i Rzemiosła TeH2O, którego inauguracja nastąpiła 20 czerwca 2015 r.. Jak piszą autorzy przewodnika szlakowego — jest to:

[...] pierwszy przemysłowy szlak tematyczny w Bydgoszczy, który łączy historię piętnastu miejsc wpisanych $\mathrm{w}$ przestrzeń miasta organicznie związanego z wodą. Każda z opowieści splata ze sobą losy bydgoszczan — rzemieślników, przedsiębiorców, społeczników z rozwojem lokalnych fabryk, manufaktur, zakładów usługowych. Nie sposób zaprzeczyć, że największy potencjał miasta stanowią, niezmiennie, jego ludzie [Kowalkowska, Dysarz-Lewińska 2016: 5] 
Ów wymiar społeczny został wykorzystany także w haśle Szlaku: Ludzie i technika przy drodze wodnej.

Rolę koordynatora Szlaku otrzymało Bydgoskie Centrum Informacji (BCI), jednak ze względu na małe możliwości osobowe już po sześciu miesiącach nastąpiła zmiana modelu zarządzania. Muzeum Okręgowe wyszło z inicjatywą i zaproponowało, by wraz Miejskim Centrum Kultury (MCK) jako 2 najbardziej zaangażowane podmioty i obiekty TeH2O - przejąć najistotniejsze role zarządcze. MOB wzięło na siebie — z początkiem roku 2016 - rolę koordynatora Szlaku, zaś MCK — wsparcia eventowego — sprowadzającego się do organizacji dorocznego Święta Szlaku — TehoFest. BCI zostało przypisane wsparcie promocyjno-turystyczne. Model zarządzania był bardziej rozbudowany i ewoluował, aż do roku 2019, kiedy to Miejskie Centrum Kultury zrezygnowało ze swojej dotychczasowej funkcji i Muzeum stanęło przed decyzją przejęcia wszystkich elementów zarządczych na Szlaku, co było nie lada wyzwaniem. Tak też się stało i we wrześniu 2019 r. MOB przeprowadziło Święto Szlaku, co związane było z koniecznością nabycia nowych kompetencji przez zespół muzealny.

Jednym z najważniejszych zadań, które stoi obecnie zarówno przez Szlakiem jak i Muzeum, które w moim przekonaniu z roku na rok zyskuje na znaczeniu, jest systemowy rozwój współpracy z branżą turystyczną. Naszym celem jest doprowadzenie do komercjalizacji oferty Szlaku (i co zrozumiał również po części MOB) poprzez opracowanie i wdrożenie parkietów turystycznych oraz stałe podnoszenie standardów usług. Zależy nam na tym by Szlak TeH2O był atrakcyjny nie tylko dla turysty z regionu województwa kujawsko-pomorskiego, ale również z kraju, a w dalszej perspektywie także dla turysty zagranicznego.

\section{POZIOM REGIONALNY}

Sieciowanie i szersza współpraca systemowa na poziomie regionalnym w województwie kujawsko-pomorskim rozpoczęła się w roku 2015 wraz z powołaniem Oddziału Kujawsko-Pomorskiego Stowarzyszenia Muzealników Polskich (SMP). W pierwszej kolejności podjęto organizację Dorocznej Konferencji Naukowej Muzealników Województwa Kujawsko-Pomorskiego. Od 2016 r. wraz z muzeami regionu, realizowane są konferencje, których celem jest prezentacja działań i osiągnięć muzealnych środowiska. Do roku 2019 odbyły się 4 edycje w: Bydgoszczy, Włocławku i dwie w Toruniu, przy czym ta ostania zrealizowana została w szerszej formule przez 
3 organizacje pozarządowe - tj. Oddział Kujawsko-Pomorski SMP oraz oddziały toruńskie Stowarzyszenia Historyków Sztuki i Stowarzyszenia Konserwatorów Zabytków, a także Muzeum Okręgowe w Toruniu i Wydział Sztuk Pięknych Uniwersytetu Mikołaja Kopernika w Toruniu. Dzięki sieciowaniu na poziomie 3 organizacji, Muzeum i Uniwersytetu konferencja zyskała zasięg ogólnopolski, większy potencjał i prestiżu.

Drugim elementem sieciujący muzea województwa kujawsko-pomorskiego były dwie edycje projektu MIASTO — LUDZIE - MUZEUM, który narodził się w głowach członków Zarządu Oddziału jeszcze w 2015 r. i którym udało się „zarazić” dyrektorów 18 muzeów.

MIASTO — LUDZIE — MUZEUM to projekt wystawienniczy zakładający realizację ekspozycji prezentujących opowieść o mieście widzianą przez pryzmat ludzi, którzy mieli znaczący wpływ (polityczny, artystyczny, społeczny, naukowy itp.) na jego rozwój. To historie mieszkańców były punktem wyjścia do prezentacji historii miast.

Wystawy były prezentowane w różnych terminach poczynając od 1 czerwca do 15 września 2017 r., tak jednak, by w okresie wakacyjnym powstała wspólna oferta pn. Kujawsko-Pomorski Muzealny Szlak Kulturowy, zachęcająca do obywania podróży i odkrywania ciekawych, a nierzadko wyjątkowych miejsc naszego regionu. Została stworzona bogata i różnorodna oferta muzealna obejmująca niema całe województwo i budująca modę na odwiedzanie muzeów na poziomie województwa.

Jeszcze w trakcie trwania projektu dostawaliśmy informacje zwrotne od osób biorących w nim udział, mówiące o tym, że gdyby nie ten projekt zapewne nigdy by nie dotarli do muzeów w mniejszych miastach.

Druga edycja projektu odbyła się 2019 r., pomiędzy 15 czerwca a 15 września - i nosiła nazwę MIASTO — LUDZIE — WOLNOŚĆ. Opierała się również na realizacji wystaw prezentujących opowieść o mieście, odnoszących się jednak do idei WOLNOŚcI, rozumianej w szerokim kontekście, nie tylko historycznym, ale również społecznym, artystycznym czy kulturowy. Ponownie w projekcie wzięło udział 18 muzeów, tworząc kolejny czasowy szlak muzealny.

\section{POZIOM KRAJOWY}

Z inicjatywy Muzeum Narodowego Rolnictwa i Przemysłu Rolno-Spożywczego w Szreniawie oraz Muzeum Okręgowego w Bydgoszczy, we współpracy programowej i przy wsparciu Narodowego Instytutu Muzealnictwa 
i Ochrony Zbiorów (NIMOZ), 13 czerwca 2016 r. w Gliwicach, powołano Forum Dziedzictwa Sztuki Inżynieryjnej - inicjatywę będącą otwartą platformą współpracy, którą mają tworzyć muzea oraz inne instytucje kultury i podmioty programowo zajmujące się dziedzictwem technicznym i poprzemysłowym, zorganizowane w sieć, w celu wypracowania i wdrożenia doktryny dziedzictwa sztuki inżynieryjnej, jego ochrony, zarządzania, upowszechniania i promocji.

Dzień przed powołaniem Forum tj. 12 czerwca również w Gliwicach odbyło się zebranie założycielskie Stowarzyszenia Muzeów Sztuki Inżynieryjnej, którego celem jest reprezentowanie interesów i wyrażanie potrzeb środowiska muzealnictwa technicznego oraz pełnienie roli zaplecza programowo-organizacyjnego dla Forum Dziedzictwa Sztuki Inżynieryjnej.

Do końca 2019 r. obyło się 11 spotkań Forum, które przybrały formę dwudniowych konferencji połączonych z wizytami studyjnymi, podejmujących różnorodną tematykę związaną z dziedzictwem i muzealnictwem technicznym, często realizowane we współpracy z samorządami [www.smsi.com.pl/ category/forum/; data odczytu: 15.06.2020]. Od dwóch lat projekt jest wspierany przez Narodowy Instytut Muzealnictwa i Ochrony Zbiorów.

\section{POZIOM EUROPEJSKI}

W roku 2015 Exploseum oddział Muzeum Okręgowe w Bydgoszczy został przyjęty do Europejskiego Szlaku Dziedzictwa Przemysłowego / European Route of Industrial Heritage (ERIH) stowarzyszenia założonego w oparciu o prawo niemieckie, które obecnie ma ponad 250 członków w 24 krajach. ERIH to duża sieć współpracy zakładająca m.in. wykorzystanie potencjału turystyki dziedzictwa przemysłowego dla lokalnego lub regionalnego rozwoju gospodarczego i upowszechnianie europejskiego wymiaru rozwoju technologii, historii społecznej i kulturalnej ery przemysłowej. Wsród 112 punktów kotwicznych - czyli perełek dziedzictwa technicznego w Europie - 10 znajduje się w Polsce [www.erih.net/i-want-to-go-there/; data odczytu: 15.06.2020].

Dzięki wstąpieniu Exploseum do ERIH `a możliwe stało się pozyskanie wiedzy, konkretnych rozwiązań i mechanizmów dot. zarządzania szlakiem kulturowym przejętych od Szlaku Zabytków Techniki województwa śląskiego. Bez funkcjonowania w strukturach ERIH`a byłoby to mocno utrudnione, a być może nawet niemożliwe. 
Podsumowując korzyści płynące z networkingu są następujące. Sieć daje możliwość transferu wiedzy i pozyskania know-how, poszerza również spektrum możliwości podejmowania inicjatyw, które w ramach instytucji muzealnej nie byłyby możliwe do realizacji. Sieć współpracy, która z założenia jest demokratyczna i nie przypisywana do żadnego konkretnego podmiotu (muzeum) daje większe szanse na realizację projektu zakładającego udział wielu podmiotów, a znajomości pozyskane poprzez sieć są bardzo przydatne w codziennym życiu muzealnym.

\section{Zastrzeżenie nazwy MUZEUM}

Na koniec rozważań chciałbym podjąć temat, który od lat rozpala muzealne głowy - mianowicie zastrzeżenia nazwy Muzeum. Obserwujemy jak z roku na rok przybywa nowych podmiotów, które w swojej nazwie używają terminu „Muzeum”, często nie mając z instytucją muzealną nic lub niewiele wspólnego — będąc kolekcjami, wystawami lub atrakcjami stricte turystycznymi. Bez wątpienia dobrze, że powstają i bez wątpienia źle, że uzurpują sobie prawo do używania nazwy Muzeum — choć w świetle obecnego prawa mogą to czynić - rozmieniając na drobne znaczenie instytucji Muzeum. Często są to podmioty o wysokich standardach obsługi ruchu turystycznego, z atrakcyjną ofertą usług kulturalnych, niemniej nie są muzeami, nie spełniają podstawowych standardów i nie posiadają profesjonalnej wiedzy w zakresie ochrony dziedzictwa - wszak nie jest to główny cel ich działalności.

Znam przykład „Muzeum” mającego uzgodniony regulamin/statut z NIMOZ-em, będącego w stanie permanentnej organizacji, które jest de facto strzelnicą i nie ma nic wspólnego z instytucją, której funkcje i formę określa Ustawa o muzeach. A jak doskonale wiadomo, takich lub podobnych przypadków w skali całego kraju jest znacznie więcej. Swoją drogą jest dość symptomatyczne to, że w ostatnich latach, by wśród podmiotów mających w nazwie termin Muzeum wydobyć te, które uznalibyśmy za pełnoprawne muzea - spełniające podstawowe wymagania — zaczęliśmy używać określenia - muzeum działające w oparciu o Ustawę o muzeach, bo samo słowo Muzeum już nie wystarcza.

Mam świadomość, iż zastrzeżenie nazwy Muzeum byłoby niezwykle trudne, ale może warto skorzystać z rozwiązań standaryzacyjnych — i nie myślę tu o poziomie Państwowego Rejestru Muzeów, którego spełnienie jest niezwykle wymagające w szczególności dla małych jednostek, ale na 
poziomie podstawowym - podmiotów funkcjonujących w oparciu o Ustawę o muzeach i wypełniających jej zapisy. Przykładem takiego działania może być rozwiązanie funkcjonujące we Francji - gdzie jak podaje prof. Aleksander Surdej w publikacji Przedsiębiorcze muzeum. Francuskie inspiracje muzea spełniające określony standard mogą posługiwać się znakiem Muzeum Francji. Te standardy to m.in.: posiadanie stałej kolekcji mającej wartość publiczną; zaangażowanie muzeum w realizację misji polegającej na konserwacji, odnowieniu, badaniu, wzbogacaniu kolekcji i jej upublicznianiu oraz prowadzeniu działań edukacyjnych. Prawo do posługiwania się znakiem mają zarówno muzea samorządowe, rządowe jak i prowadzone przez osoby prawne (stowarzyszenia i fundacje) nie nastawione jednak na zysk. Posiadanie znaku uprawnia o ubieganie się o pomoc państwa w różnych zakresach: naukowym, finansowym czy też technicznym. Znak nie jest przyznawany w sposób nieodwołalny, muzeum — jeśli nie respektuje określonych warunków - może go stracić. Instytucja znaku — Muzeum Francji została wprowadzona w roku 2004 i do końca 2016 r. przyznano go 1218 instytucjom [Surdej 2019: 61]. W moim przekonaniu to interesujące rozwiązanie, któremu warto się przyjrzeć bliżej.

\section{Podsumowanie}

Jakie są nowe trendy w muzealnictwie? Czym jest nowoczesne muzeum? Czy jest nim muzeum wypełnione najnowocześniejszymi technologiami i urządzeniami? W moim przekonaniu nowe technologie mają znaczenie jedynie jako narzędzia, a nie podmioty naszych starań. Jeśli wiemy, jak je wykorzystać, by nie przyćmić muzealiów i opowieści, a wręcz przeciwnie - wzmocnić je - to oczywiście warto ich używać. Jeśli jednak powodem zastosowania - często znaczącej liczby - multimediów jest chęć epatowania technologiami i osiągnięcia efektu wow, to warto być wstrzemięźliwym - bo nic się tak szybko nie starzeje jak nowe technologie, a jeśli decydujemy się na ich użycie, powinny stać za tym konkretne argumenty merytoryczne.

Nowoczesne muzeum to takie, które w swojej działalności stawia mocny akcent na odbiorcę/uczestnika, wchodzi z nim w dialog i buduje relacje. Takie, które tworzy opowieści o dziedzictwie, tożsamości, wartościach i rzeczach ważkich - obecnie nas dotykających, z którymi jako ludzie się mierzymy. 
To muzeum, które może być trzecim miejscem (lub w jego kierunku zmierzać), miejscem atrakcyjnego, rozwojowego spędzania wolnego czasu, w którym się dobrze czujemy i do którego chcemy wracać.

To muzeum, które dba o swoją publiczność, starając się przygotować ofertę możliwe najbadziej interesującą i aktywizującą, które traktuję odbiorcę jak partnera, z najwyższymi standardami.

To muzeum, które ma w sobie dużą dozę artyzmu, kreatywności i misyjności, funkcjonujące w oparciu o przemyślane i sprawdzone standardy oraz dokumenty strategiczne, a także skuteczny systemem kontrolny i ewaluacyjny.

To także muzeum przedsiębiorcze, znające swoją wartość i mocne strony, konkurujące z podmiotami komercyjnymi na rynku czasu wolnego, badające swoją publiczność i niepubliczność, by zgromadzić wiedzę o jej preferencjach i potrzebach. To instytucja innowacyjna, odważnie wprowadzająca do swej oferty nowe rozwiązania.

Nowoczesne muzeum to instytucja osób twórczych, która umożliwia im aktywne funkcjonowanie w danej rzeczywistości i szybkie reagowanie na dynamicznie zachodzące zmiany. To miejsce, które jest ważne dla społeczności i bez którego ta społeczność nie wyobraża sobie funkcjonowania.

\section{Bibliografia}

\section{Freeman Tilden}

2019: Interpretacja dziedzictwa, Poznań: Brama Poznania.

\section{Hajduk Joanna, Piekarska-Duraj Łucja, Idziak Piotr}

2013: Lokalne muzeum w globalnym świecie — poradnik praktyczny, Kraków: Małopolski Instytut Kultury.

Hibner Elżbieta, Łysik Kamil, Pater Renata, Skotnicka-Illasiewicz Elżbieta, Stępień Jerzy, Surdej Aleksander, Wrede Julia, Rataj Waldemar

2012: RAPORT. Strategia Rozwoju Muzealnictwa. Założenia programowe, Warszawa: Narodowy Instytut Muzealnictwa i Ochrony Zbiorów.

\section{Jagodzińska Katarzyna}

2018: Muzea poza murami w kontekście koncepcji trzeciego miejsca [w:] Muzealnictwo, Warszawa: Narodowy Instytut Muzealnictwa i Ochrony Zbiorów.

\section{Kowalkowska Agnieszka, Dysarz-Lewińska Małgorzata}

2016: Szlak Wody, Przemysłu i Rzemiosła w Bydgoszczy. Przewodnik, wyd. 2 popr., Bydgoszcz: Muzeum Okręgowe im. Leona Wyczółkowskiego w Bydgoszczy.

\section{Krajewski Marek}

2013: W kierunku reakcyjnej koncepcji uczestnictwa w kulturze, „Kultura i społeczeństwo", nr 1. 


\title{
Matt Gerald
}

2006: Muzeum jako przedsiębiorstwo. Łatwo i przystępnie o zarządzaniu instytucja kultury, Warszawa: Fundacja Aletheia.

\section{Niezabitowski Michał}

2015: Zwiedzający — widz czy aktor współtworzący doświadczenie muzealne? Uwagi na temat zmian determinujących recepcję muzeum, [w:] I Kongres Muzealników Polskich, Warszawa: Narodowe Centrum Kultury.

\section{Surdej Aleksander}

2019: Przedsiębiorcze muzeum. Francuskie inspiracje, Kraków / Paryż: Limes Publishing — https://bramapoznania.pl/files/przedsiebiorcze-muzeum-surdej.pdf

\section{Wasilewska Joanna}

2019: Spór o nową definicję muzeum na konferencji generalnej ICOM w Kioto, „Zbiór Wiadomości do Antropologii Materialnej”, nr 6.

\section{Źródła niepublikowane}

\section{Wisłocki Krzysztof}

2019: Wybrane aspekty współdziałania uczelni technicznych i muzeów w ochronie zabytków sztuki inżynieryjnej podczas konferencji naukowej Technika i nauka w muzeum, Bydgoszcz, 25.09.2019.

\section{Strony internetowe}

https://mfiles.pl/pl/index.php/Networking [data odczytu: 15.06.2020]

http://smsi.com.pl/category/forum/ [data odczytu: 15.06.2020]

https://www.erih.net/i-want-to-go-there/ [data odczytu: 15.06.2020].

\section{Marcin Zdanowski}

\section{(New) trends in museology - a subjective view}

\begin{abstract}
The article presents (in subjective terms) the directions of museology development, and shows issues related to the change of approach to museum audience. It is indicated that the viewer, recipient, or even participant, is more and more often placed in the center of the interest of a contemporary museum. The article pays attention to the change in museum's attitude in recent years. The once common transfer of knowledge, was changed to stimulating thinking and personal development. The set point for this attitude can be, the still little known, though dating back to 1957, Tilden's principles of heritage interpretation. An attempt was also made to transfer Ray Oldenburg's theory of Third places to museum context. In addition, arguments for an entrepreneurial and strategic approach to museum functioning and management were presented. Furthermore, a number of examples were shown, supporting the thesis that building a network of relationships and partnerships is one of the most interesting and effective tools in managing a contemporary museum.
\end{abstract}

Keywords: museology, entrepreneurial museum, heritage interpretation, third place, networking 